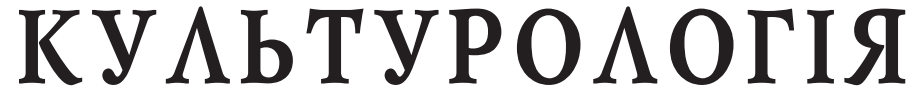

DOI: https://doi.org/10.32839/2304-5809/2020-12-88-19

УДК $745 / 749$

Михайлова T.С. ${ }^{1}$, Шандренко O.M. ${ }^{2}$

Київський національний університет культури і мистецтв

\section{ЕТНОДИЗАЙН В ПАРАДНІЙ ОЛІМПІЙСЬКІЙ ФОРМІ}

Анотація. Запропоновано інформаційно-концептуальну дизайн-ідентифікацію парадної фрорми одягу збірної України на прикладі Олімпіади 2021 року. Україна має унікальну яскраво виражену історико-культурну ідентичність, яка була сформована завдяки багатьом фракторам, але нова система комунікацій потребуе творчо відкритих та цілісних сучасних інтерпритацій етнічних символів в дизайні. Концепція базуеться на візуалізації одягу який ідентифікуе українську націю та одночасно висвітлюе ідеї, проблеми та реалії сьогодення. Запропоновані ідеї е частиною загальної айдентики змагань, які не порушують правила, які регламентують документи затверджені Міжнародним олімпійським комітетом. Для вирішення поставлених завдань на емпіричному і теоретичному рівні використовувалися загальнологічні методи дослідження візуального, літературно-системного порівняльного аналізу закордонного та вітчизняного досвіду.

Ключові слова: етнодизайн, Олімпійські ігри, олімпійська парадна фрорма, імідж, бренд країни, ідентичність, візуальна ідентичність.

Mikhailova Tetyana, Shandrenko Olga

Kiev National University of Culture and Arts

\section{ETHNODESIGN IN THE CEREMONIAL OLYMPIC UNIFORM}

Summary. Researched the specifics of the development of ceremonial uniforms and the use of visual forms of identity during the Olympic Games in a social environment are studied. On the examples of design-visualization of the Olympic uniform the conceptual principles of ethnic design and their specifics in the context of a modified advertising strategy that meets the modern needs of the target audience are identified. The information-conceptual design-identification of the ceremonial uniform of the national team of Ukraine on the example of the 2021 Olympics is offered. The Olympic ceremonial costume is an interesting and little-studied object for science. The figurative characteristic of a suit as an aesthetically significant multilevel object represents unity of personal and social, this unity also defines philosophy of an art image. The artistic image of the costume evokes an emotional response. The process of perceiving the Olympic uniform as a manifestation of non-verbal communication system consists of several stages, which includes, above all, visual assessment of proportions, the ratio of the volume of the figure and clothing, the decision on the color scheme. "Reading" in the costume of cultural meaning depends on the intellectual and spiritual development of the perceiving person. Ukraine has a unique pronounced historical and cultural identity, which was formed due to many factors, but the new system of communication requires creatively open and holistic modern interpretations of ethnic symbols in design. Concept is based on the visualization of clothing that identifies the Ukrainian nation and at the same time reveals the ideas, problems and realities of today. The Olympic ceremonial form is an important object for scientific research. One of the important strategic tasks of the developers of the elements of the Olympic uniform is to make it possible for the consumer to express the formulated philosophy of the national team and the Olympics in general. An important part of developing a design project is to create an accurate identity that reflects the idea, goals, priorities and mood that is conveyed in each item of clothing. Identity allows us to focus the consumer's attention and show a modern image of the territory, which allows us to define the country as a producer, bearer of cultural values and places where technology, infrastructure, transport, tourism, sports and more are located. The proposed ideas are part of the overall identity of the competition, which does not violate the rules governing the documents approved by the International Olympic Committee.

Keywords: ethnodesign, Olympic Games, Olympic ceremonial uniform, image, country brand, identity, visual identity.

Постановка проблеми. Історичні аспек1 ти формування України як незалежної держави наочно демонструють, як ідеологічні індормаційні маніпуляції знецінюють нашу національну символіку, мову, традиції. Існує потреба представити символи національної української ідентичності на світовому рівні в новій концептуальній моделі. Економічні, політичні, культурно-національні питання загострюються між країнами, в наслідок цього відбувається переосмислення територіальних просторових меж. В інформаційно-глобалізованій реальності постає проблема національної ідентифікації та самосвідомості.

Аналіз останніх досліджень і публікацій. Людина в усі часи змінювала рівень умов власного буття, використовуючи різноманітні способи впливу на інших індивідів на суспільному рівні та в цілому. Реклама завжди була одним із найефрективніших способів такого впливу. В локальних небагатолюдних племінних умовах особливої необхідності в рекламі, як відгалуженні масової 
комунікації, не було. Але існують дослідження, в яких етнографи та антропологи виявили історичні повідомлення про набір комунікативних текстових та графрічних прийомів, що були сфрормовані в умовах давньої культури. Багатогранним є і рекламний досвід людства, який поєднує інформаційні, комунікаційні, ідеологічні, культурні, виховні, соціальні, економічні, керуючі та маркетингові фоннції реклами [9]. Історичні аспекти дизайну щодо вивчення семантики геральдичних символів досліджували Ж. Руа, Н. Стародубцева, Ф. Функен та інші. Семантику кольору, його культурологічні та комунікативні аспекти композиційного фрормоутворення в графріці досліджували I. Іттен, А. Костіна, Н. Серов, С. Прищенко, В. Папанек. В контексті авторської концепції розглядали прийоми для побудови малюнка та проблеми відповідності графіки орнаменту текстильного полотна I. Яковець, Н. Романенко, Ю. Борисов.

Дизайн-проєктування при створенні нових форм спецодягу, в тому числі одягу для спортивних змагань аналізували М. Колосніченко, Л. Білоцька, Ю. Харченко, О. Нахайчук, Е. Захарова, Л. Кондратьєва, I. Коваленко. Питання територіального бренду достатньо досліджені в різних напрямках, наприклад, таких як: співвідношення стосовно території категорій «бренд», «імідж» i «репутація»; методи залучення цільових аудиторій і стейкхолдерів в процес розробки територіального бренду; виявлення і визначення ідентичності територіального суб'єкта. Цю проблематику розглядали I. Важеніна, Ю. Смирнова, Д. Гавра, Е. Степаничева, Л. Старостова, С. Анхольт, М. Каваратзіс, Д. Візгалов. Питанням етнодизайну присвячені роботи Ю. Афранасьєва, Є. Антоновича, О. Кудря, Ю. Легенького, P. Захарчук-Чугая, С. Прищенко, К. Тимочко та інших науковців. В сучасному дизайні одягу О. Данилова розглядає використання етно орнаментів. В контексті проєктних стратегій формотворення в дизайні одягу О. Шандренко висвітлює питання етномистецтва як джерела модифікації.

Виділення невирішених раніше частин загальної проблеми. Під час дослідження було виявлено що національна ідентифікаційна символіка в дизайні олімпійської парадної форми $є$ не достатньо дослідженою та потребуе поглибленого вивчення та наукового обгрунтування.

Мета дослідження. Визначити концептуальні засади етнодизайну і його специфіку на прикладі олімпійської парадної форми як ідентифрікатора бренду країни. Дослідження пов'язане з аналізом візуальної ідентичності парадної фрорми 3 національною символікою країни.

Виклад основного матеріалу. В Давній Греції, у 776 р. до н.е. під час проведення перших Олімпійських ігор зародився Олімпійський спорт. Більше тисячі років ОI проводилися регулярно, але завершився давньогрецький цикл у 394 р. н. е. Вже в сучасних умовах історії кінця XIX ст. спортивні змагання відродилися. Ідеали OI Давньої Греції мають охоплення світового масштабу, їх покладено в основу сучасного олімпійського руху. Аналізуючи феноменом життя світового суспільства, можна сказати, що Олімпійський рух має надзвичайну стабільність, а спортивна освіта, виховання поєднуеться 3 філо- софськими, соціальними, економічними та політичними аспектами, що зробило його універсальним явищем [5, с. 7].

Еволюція дизайну олімпійського одягу, як i еволюція Олімпійських ігор пройшли довгий і складний шлях розвитку і не одразу набули великої популярності, впливовості та притаманних їм рис і масштабів. Тому історія Олімпійських ігор та історія розвитку формування дизайну олімпійського одягу тісно пов'язані між собою. Ідея одягнути спортсменів з однієї збірної в однакову форму вперше прозвучала 84 роки тому під час літніх OI в Берліні 1936 року [12]. Саме тоді почався олімпійський фешшн-марафон і шалена конкуренція серед дизайнерів, яким довіряли створення олімпійської парадної форми. На сучасному етапі розвитку, система візуальних комунікацій потребує творчо відкритих та цілісних сучасних інтерпритацій символів в дизайні. Для того, щоб розробити дизайн парадного олімпійського одягу, який правильно позиціонує та ідентифрікуе країну, необхідно проаналізувати і оцінити вплив елементів національної символіки та їх використання під час дизайн-проєктування олімпійської форми.

Народність, етнос, фрольклор є популярною темою в основних сферах діяльності людини: мистецтво, література, мода, 3МI. Актуальність звернення до національної культури даного напрямку очевидна. Етнодизайн поєднує художньо-естетичну, етнічну, конструктивну i технологічну складову сучасного проєктування. Засобами етнодизайну є зображально-виражальні та загальні для дизайну і пластичних мистецтв: колір, пропорція, текстура, форма, точка, обсяг і простір. Мистецькі сучасні практики на сьогоднішньому етапі пробудження національної самосвідомості актуалізують фольклорні фестивалі, образотворче мистецтво та предмети побуту. В перекладі слово етнос (грец. ethnos) означає - народ, група, плем'я. Характерними проявами етносу в мистецтві є національна символіка, мотиви, колористика та ін.

Ю. Легенький визначає, що «...етнодизайн це нова парадигма бачення складного комплексу народної, ремісничої та професійної культури. Розвиток дизайну з етнічними елементами свідчить про новий період у культурному розвитку українців, який неминуче повинен пробитися крізь товщу універсалізму. Дизайн формуе людину і впливає на неї, на їі психіку та поведінку. Розробка і впровадження нового етностилю повинні спонукати до відродження елементів традицій, обрядовості, до бажання ідентифікації з українським народом» [6, с. 17]. О. Шандренко розглядає етномистецтво, як сукупність творчих процесів людини, пов'язаних із освоєнням (пізнанням) світу (космосу), направлених на створення творів мистецтва із збереженням устрою, традицій, ладу певного народу, нації [8]. Є. Антонович зазначає, що універсальність нащіональної культури як феномену інтегруе досягнення українського народу [1].

Д. Гавра виділяе зовнішній i внутрішній імідж певної території. На його думку, зовнішній імідж території - це «загальний, що складаеться з набору переконань і відчуттів, оцінка уявлень про неї (свідоме чи несвідоме), що складаються 
у не представників цієї території». Внутрішній імідж визначається як «відповідний образ-уявлення про регіон, що склався у його представників». В рамках даного підходу Д. Гавра виділяе три іміджевих формати - безпосередній імідж (складається по відношенню до територіально-державного суб'єкта в ході відвідин країни), опосередкований імідж (складається в ході сприйняття зовнішньої індрормації про суб'єкта) і змішаний імідж (виникає на основі сприйняття інформації 3 мас-медіа) [4].

Імідж - це самопозиціонування бренду, «імідж - це заявлений образ, або заявлена позиція» (цит. за А. Чумиковим) [11]. Образ, що лежить в основі іміджу - цілісний, конкретний і унікальний. Імідж являє собою ідеальну позицію, яка конструюється спеціально або цілеспрямовано. Імідж плануеться і просувається для споживачів. Головною фонкцією іміджу $є$ фрормування позитивного відношення до соціального суб'єкту. Бренд є послідовним комплекс, який включає в себе набір фонкціональних, емоційних, психологічних та соціальних чинників, які максимально відповідають потребам споживача. Репутація існуе в комунікаційному полі являючи собою сприйняту позицію (сприйнятий образ). На відміну від іміджу, який грунтуеться на емоційних уявленнях, репутація безпосередньо залежить від конкретних дій з боку суб'єкта. Якщо імідж можна цілеспрямовано створити, то репутація включає в себе комплекс заходів з управління вже сприйняттям іміджу. I. Важеніна i C. Важенін визначають репутащію території як «об'єктивно сформовану і піддану практикою сукупність ціннісних переконань і раціональних думок про території, які фрормувалися у людей (людини) на основі отриманої достовірної інформації про територію, особистого досвіду взаємодії або опосередкованих контактів» [3]. На думку авторів, бренд, імідж і репутація регіону є нематеріальними активами території. Всі три компоненти - бренд, імідж і репутація території $\epsilon$ пов'язаними i взаємодоповнюючими. Можемо зробити висновок, що особливістю даних категорій є те, що кожна 3 них базуеться на асоціаціях, образах і уявленнях, які складаються в підсвідомості аудиторії під час взаємодії з країною або їі представниками. Бренд країни будуеться в тому випадку, якщо територія має позитивний імідж: в такій ситуації, територіальний бренд підсилюе імідж нації. С. Анхольт вперше вжив термін фрірмовий бренд (англ. - place branding) стосовно територій в 2002 році, а трохи пізніше представив теоретичне обгрунтування територіального бренду, розробивши модель ідентичності територіального бренду. На його думку, територіальний бренд формуеться навколо п'яти основних вимірів: зовнішньої політики, просування туризму, експорту брендів, залучення інвестицій, репрезентація культури, які за допомогою своєї діяльності передають інформацію в зовнішній світ і формують образ території. Туризм і відпочинок найбільше впливають на формування бренду нації, експортні товари формують образ країни за кордоном, політичний курс країни фороуе дипломатичні відносини, представники ділового кола обмінюються інформацією про сприятливості бізнес-середовища, культурна складова пропагуе культурну спадщину, а ментальність населення проявляеться як в їх поведінці закордоном, так і в їх гостинності і відображає основну специфіку життя в країні людей [2]. Ця модель $€$ однією 3 найбільш наочних, вона структурує поняття ідентичності бренду країни. Залучення туристів має позитивний вплив на розвиток країни, так як туризм $є$ одним 3 ключових напрямків розвитку економіки. Туристи приїжджають 3 метою відвідати значущі і унікальні культурно-історичні, природні чи інші об'єкти, що володіють особливою значущістю. Крім теоретичного обгрунтування територіального бренду в системі чинників його розвитку, В даному аспекті мова йде про унікальну ідентичність парадного олімпійського одягу збірної країни. В цьому випадку підтвердження іміджу в кінцевому підсумку впливає на підвищення уваги до бренду на міжнародному рівні.

Ідея одягнути спортсменів з однієї збірної в однакову форму вперше прозвучала на літніх ОI в Берліні 1936 року. Саме з 1936 року почався олімпійський фрешн-марафон і шалена конкуренція серед дизайнерів, яким довіряли створення олімпійської форми одягу. Міжнародний олімпійський комітет контролюе національні збірні під час змагань. За закріпленими правилами комітету форма національних збірних не може повторюватися. Створенням олімпійської фрорми для спортсменів в різний час займалися видатні дизайнери світового рівня, такі як: Coco Chanel, Yves Saint Laurent, Giorgio Armani, Pierre Cardin, Jacques Esterel та багато інших. Приблизно 3 80-х років традиція пошиття олімпійського одягу перейшла до великих компаній, однак бажання одягнути спортсменів не тільки комфрортно, але і модно, нікуди не зникло, кожна церемонія відкриття ОI - це своєрідне фешн-шоу [13].

Прикладом реалізації загальної екіпіровки стала поява в програмі OI змагання з мистецтва арт-компетейшн (art competition). Змагання в мистецькому контексті проводилися з 1912 по 1948 рік, потім трансформувалися в практику олімпійських культурних програм. Використання змагальної екіпіровки та інвентарю відповідало духу спортивного заходу, одночасно це підвищувало рейтинги за допомогою театральності. Але в остаточному підсумку перемогла стратегія ідентичності олімпійської форми, яка передбачала єдину для збірних країн форму, спеціально розроблену для церемонії. Спеціальна парадна уніформа для церемонії відкриття в історії Олімпійського руху з'явилася раніше таких символів, як олімпійський прапор (1920 рік), запалення вогню в спеціальній чаші (1928 рік) та естафета олімпійського вогню (1936 рік) [14].

Вперше втілення нащіональної ідентичності в олімпійській костюмній історії відбулося під час виступу грека Спиридона Луїса (Spyridon Luis), чемпіона в бігового марафону, який переміг в Аdpiнах в 1896 році. На церемонії нагородження та параді призерів Luis, з'явився в традиційному грецькому костюмі зі спідницею-фрустанелла. Чемпіон мав досвід служби в армії, де фрустанелла в ті часи була частиною уніформи. Завдяки перемозі в марафроні, яка, за спогадами очевидщів, була особливо важлива для греків, Spyridon Luis став загальнонаціональним героєм. А фрустанелла була 
символом боротьби проти турецького панування і сприймалася в Грещії того часу як справді національний одяг [16]. В олімпійській парадній фрормі стратегія 3 використанням елементів традиційної сукні має свої слабкі сторони. Зокрема, у багатьох країнах такі елементи традиційного костюма, як фрустанелла, з часом перестали користуватися популярністю. Згодом на ОI виробилися власні підходи до конструювання «національного» в костюмі, в даному випадку більш універсальні. До таких можна віднести, зокрема, традищію використовувати кольори і елементи прапора країни (смуги, герби, хрести, зірки та інші елементи). Сьогодні важко собі уявити, що це не завжди було нормою. Дивлячись на велику кількість делегацій середини другої половини XX ст., далеко не завжди можна відразу визначити, яку саме країну вони представляють, оскільки колір парадної олімпійської форми, очевидно, обирався довільно. Кольори прапора та інші нащіональні кольори частіше використовувалися в аксесуарах: краватках, шийних хустках. Сучасні правила екіпіровки, встановлені МOК і міжнародними спортивними федераціями, навпаки, заохочують використання в олімпійській екіпіровці «національних кольорів, назв, гербів, прапорів і емблем, а також емблем МОК, які допомагають "візуально підкреслити національну приналежність збірних» [10]. З одного боку, це продиктовано міркуваннями практичного характеру: допомагає відрізняти спортсменів в телетрансляції і на великому стадіоні. Разом з тим самі учасники змагань відзначають, що носити національні кольори - це досвід, пов'язаний зі специорічними переживаннями.

Ha прикладі Spyridona Luisa в Adpiнax в 1896 році ми бачимо спробу вбудувати в парадну олімпійську форму елементи традиційної сукні, що виконуе роль національного костюма в ширшому, ніж спортивний, контексті. У 1960 році журнал Sports Illustrated назвав парад спортсменів на Олімпіаді в Римі «етюдом про національні смаки в одязі», однак спектр екзотичності був, судячи 3 прикладів, далеко не таким широким, як сьогодні. У фрокус уваги потрапили чисто виголені кубинці без борід "як у Фіделя», представники Бермудських островів, які «були буквально в шортах» та спортсмени 3 Ліберії в оброблених золотом фесках, яскраво-червоних піджаках і білих брюках, а також пакистанських білих тюрбанах [11]. Тим, що подібний підхід до парадної олімпійської форми існуе і сьогодні, ми багато в чому зобов'язані представникам Адрики, які поступово поповнювали «олімпійську сім'ю» в другій половині XX ст., а також представникам Близького Сходу, Південно-Східної Азії і Океанії. Афрриканські делегації вже в 1960 році в якості парадної олімпійської формии часто обирали одяг, прямо відтворюючи традиційне або ритуальне плаття або надихалися його формами. Наприклад, в 1970-1980 роках можна було побачити запозичені з традищійного костюма форми плащів, накидок, які були виконані в пастельних тонах і позбавлені звичного для африканських тканин орнаменту. Розглянемо приклади візуальної ідентичності олімпійського парадного одягу.

1908 рік, IV літні OІ у Лондоні. Збірна Канади була однією із перших хто продемонстрував ві- зуальну ідентиоікацію одягу з айдентикою своєї країни. Представники ціеї країни були одягнені в недормальні для олімпійського одягу того часу світлі брюки i джемпери 3 великим кленовим листом на грудях, кепками в тон кольорового ансамблю і контрастними краватками [12].

1928 рік, IX літні OI у Амстердамі. Кожен представник голландської спортивної збірної був забезпечений однаковими блейзерами з відображенням на лівій стороні грудей фрігур золотих левів на помаранчевому тлі та чорною краваткою. Також збірна була одягнена в білі брюки (жінки в спідниці) такого самого кольору і взуття, а солом'яні капелюхи прикрасили помаранчевою стрічкою [18].

1936 рік, XI літні ОI в Берліні. Спортсменки збірної Голландії були одягнені в світлі прямі спідниці в складку і жіночні жакети без гудзиків схоплені на талії ремінцем. На нагрудній кишені розміщений герб Королівства. Взуті однаково, білі туфлі на невеликому акуратному каблуку з ремінцями виглядали урочисто. Коли відбулося відновлення ОI після Першої світової війни більшість команд на літніх церемоніях обирали для параду спортсменів уніформу єдиного зразка, відмовляючись від змагальної екіпіровки та інвентарю. Хоча термін «офріційна уніфрорма» в описі регламенту церемонії відкриття 3'являеться в Олімпійській хартії тільки в 1949 рощі: до цього стосовно спортсменів, які беруть участь в параді, використовувалося фpopмулювання «одягнені для участі в Іграх» (dressed to take part in the Games) [17].

1984 рік, XXIII літні OI в Лос-Анджелесі. Парадну уніформу американської збірної обрали народним голосуванням. Компанія Levi Strauss \& Company запропонувала відвідувачам магазинів на вибір три варіанти схвалених національним олімпійським комітетом: спортивний (Active), класичний (Classic) і в стилі ковбойського Дикого Заходу (Western). Майже половина тих, хто проголосував, висловилися за спортивні костюми в кольорах національного прапору [15].

2008 рік, XXIX літні OI в Пекіні. Бразильська збірна представляла свою країну в кольоровій гамі свого прапора. Соковиті зелені піджаки, чорні штани для чоловіків, спідниці для жінок, а також білі панами.

2012 рік, XXX літні OI в Лондоні. Американська збірна в повній мірі продемонструвала свій патріотизм. Спортсмени вийшли в біло-синіх костюмах в стилі «Рreppy», який нагадуе "smart casual». Дизайн парадної форми належить знаменитому Ralph Lauren. Темно-сині жакети 3 золотими гудзиками і біла спідниця А-силуету трохи нижче коліна. Ralph Lauren також продумав аксесуари: акуратний бере і тонкі шарфи в кольорах національного прапора, які надавали образу невеликий «наліт» паризького шику.

2014 рік, XXII зимові OI в Сочі. Олімпійську форму для збірної України розробила компанія BOSCO, взявши за основу сакральний український символ - колосок пшениці. Комплект одягу: повністю вкрита орнаментом спортивна куртка, чорні спортивні брюки, шапки та шарфри жовтого кольору. За рейтингом олімпійської форми у Сочі-2014 року, який склав видання USA Today, одяг української збірної потрапив до 
списку найгіршої парадної фрорми. Можна зробити висновок, що дизайнери перестаралися зі стилізацією колоску пшениці, зробивши орнамент схожим на 3D-малюнок. Також в цей антирейтинг разом зі збірною України потрапили спортивні збірні Литви, Франції, Великої Британії та Канади.

2016 рік, XXXI літні OI в Ріо-де-Жанейро. Над дизайном олімпійської форми працювала студія Самоселі Пірвелі (Samoseli Pirveli). Парадний одяг був схожий на національне грузинське вбрання "чоха". В Грузії розгогрівся політичний скандал. Феміністок обурило занадто довге консервативне вбрання, яке не відображало умов сучасного суспільства [14].

2018 рік, XXIII зимові OI в Пхьончхан. Збірну Франції втрете поспіль екіпірував модний бренд, заснований тенісистом Rene Lacoste. Ha знакових для бренду сорочках-поло зчитується знаменитий фрранцузький триколор. За дизайн одягу для збірної Білорусії відповідала дизайнер Людмила Лабкова. Вона створила «парадно-громадянську" уніформу для церемоній відкриття і закриття Олімпіади, в основі якої виявилися національні мотиви. Орнамент, який символізує мати і оберіг з додаванням елементів, які означають удачу, успіх і врожайність. За дизайн спортивної уніформи відповідав литовський бренд Audimas.

2021 рік, XXXII літні ОI в Токіо. Форму для збірної США вже анонсував дизайнер і засновник KITH Ronnie Fieg. 20 липня бренд випустив два спортивних костюма і два варіанти кепок. Іншу частину колекції представлять напередодні ОI літом 2021 року. Костюми в чорно-білому забарвленні доповнили синіми, червоними і сріблястими смугами на рукаві і холоші - 3 відсиланням до кольорів американського прапора, а також вставками з олімпійськими кільцями, прапором США. На кепках також розмістили п'ять олімпійських кілець і букви USA.

Деконструкція прапорів та інших національних символів в сучасній олімпійської парадній формі буває досить сміливою. Елементи компонуються в довільному порядку, змінюють колір i конфрігурацію, стають принтом. У 2012 році дизайнер Stella McCartney зазнала критики за переклад британського «Union Jack» в синьоблакитну монохромну гамму. Дизайнер, в свою чергу, виправдовувалася бажанням зробити щось «сучасне». Зустрічається і використання кольорів, які традиційно асоціюються 3 країною, принаймні в спортивному контексті, як помаранчевий 3 Нідерландами або чорний 3 Новою Зеландією. Також варто згадати практику включення в дизайн різних видів олімпійської форми текстових елементів. Збірна Італії часто носить цитати з національного гімну, а американські спортсмени девізи «Земля свободи» i «Будинок хоробрості». На австралійських олімпійських парадних блейзерах 2016 року були написані імена олімпійських чемпіонів минулих років, а корейська парадна олімпійська форма включала напуття від уболівальників. Оскільки офіційні олімпійські правила не заохочують написи на уніфрормі, найчастіше вони розташовані на підкладщі, внутрішньої устілки, в глибині шва та інших місцях, де їх складно розглянути стороннім [10].
В цілому можна констатувати, що діапазон культурних відсилань, які використовуються для парадної олімпійської форми, цілком відображає традиційне визначення нації як «великої групи людей, об'єднаних спільним походженням, історією, культурою або мовою». Олімпійський парадний дрес-код за останні десятиліття став більш демократичним, але уявлення про унірорму як про візитну картку країни збереглося. Окремої уваги заслуговуе еволюція парадної олімпійської форми. В цілому сьогодні можна виділити три основні костюмні стратегії для літніх Ігор, які традиційно мають більш широке географрічне представництво. Класичні костюми з піджаками, різні форми традиційних суконь, франтазії на етнічну тему, спортивний або вільний стиль.

Кольорове рішення. Обираючи кольорову гамму при оформленні одягу, зазвичай враховується її вплив на емощійний настрій споживачів і обираються поєднання, які надають сприятливий психологічний вплив на них. Відображення етнічності в мистецтві супроводжується наявністю великої кількісті візуальних символів, що відображають історію виникнення, створення і розвиток певного народу. Під час розробки орнаменту який наноситься на одяг олімпійської колекції ми звернулися до етнічного елементу української культури. Ідея поєднати сучасну інформаційноідеологічну конщепцію з етносимволами полягає в підкресленні національної ідентичності України. Головне завдання орнаменту на одязі та його елементах - це популяризувати та стилізувати українську символіку, а головний меседж - це презентація України як родючої процвітаючої аграрної держави. Стилізація орнаменту на одязі візуально ідентифікуе спортсменів з Україною та поєднуе гамму кольорів в рамках якої дизайнпроєкт парадного одягу.

Авторська інформаційно-концептуальна дизайн-ідентифікація парадної форми одягу збірної України на прикладі Олімпіади 2021 року базуеться на принципах візуалізації одягу, який ідентифікує українську націю та одночасно вісвітлює ідеї, проблеми та реалії сьогодення.

Місія парадного одягу збірної України до Олімпіади-2021 року: 1) сприяти підвищенню престижу української нації на світовому рівні; 2) популяризувати та стилізувати символи країни; 3) закріпити імідж і репутацію европейської держави з інтероперабельним світосприйняттям людини такою, яка вона $є ; 4)$ залучити наших співвітчизників до ідеалів ОI; 5) позитивно вплинути на новий етап відносин між Україною та іншими країнами-учасницями Олімпіади.

Принципи, на основі яких базуеться ідея авторського проєкту олімпійської парадної форми: відкритість, об'єднаність, креативність, доброчесність, комунікативність та екологічність.

Важливою частиною розробки проєкту олімпійської форми є створення влучної айдентики, яка відображає ідею, щілі, пріоритети та настрій який передається в кожному елементі. Айдентика дозволяе концентрувати увагу споживачів та показати сучасний образ території, що дозволяе ідентифікувати країну як товаровиробника, носія культурних цінностей та місця, в якому розвиваються технології, інфраструктура, транспорт, туризм, спорт та інше. В даному випадку ми створюемо рекламну 
візуальну комунікацію з аудиторією, яка повинна позитивно сприймати наш продукт.

Цінності, які пропагуе запропонована інформаційно-концептуальна дизайн-ідентифрікація парадної форми одягу збірної України на прикладі Олімпіади 2021 року:

- Цінність національної ідентичності. Історичні аспекти формування України як незалежної держави наочно демонструють, як ідеологічні інформаційні маніпуляції знецінюють нашу національну символіку, мову, традиції. Існуе потреба представити символи національної української ідентичності на світовому рівні в новій сучасній концептуальній моделі.

- Цінність людського життя. Не важливо які в тебе вік, вага, стать, расова приналежність чи сексуальна орієнтація. Ми - люди, духовність, моральні цінності, освіта та спроможність критично мислити допомагають нам знаходити спільну мову і залишатися толерантними один до одного.

- Цінність товариських відносин між країнами. Олімпійські ігри є надзвичайно потужною мультидисциплінарною платформою, де існують сприятливі умови для налагодження відносин на різних комунікаційних рінях.

Кольорова гамма в якій запропоновано дизайн-проєкт зумовлений: 1) стратегією візуальної ідентичності кольору щодо приналежнасті спортивної збірної до України; 2) начення та сприйняття кольорів в приймаючій ОI країні; 3) на основі прогнозування тенденцій Інституту кольору і консалтингової компанії Pantone.

Висновки i пропозиції. Олімпійський парадний костюм є цікавим об'єктом для дослідження. Це одночасно і універсальна фрорма, яка допомагає ідентифікувати «своїх», і костюм, що відображає національну приналежність і «дух нації», i «модний» продукт, який оцінюеться відповідним чином. Дизайн одягу $є$ креативною платформою яка невпинно розвивається. В дослідженні запропоновано інформаційно-концептуальну дизайн-ідентифрікацію парадної форми одягу збірної України на прикладі Олімпіади 2021 року. Концепція базуеться на візуалізації одягу який ідентифрікуе українську нащію та одночасно висвітлюе ідеї, проблеми та реалії сьогодення. Запропоновані ідеї є частиною загальної айдентики змагань та не порушують правила, які регламентують документи затверджені Міжнародним олімпійським комітетом. Тенденції в моді фіксують стан суспільства, культури і мистецтва. Основні питання, проблеми, події соціального, політичного, культурного життя людей знаходять свое відображення в концептуальних рішеннях дизайну. Кожен елемент на олімпійській парадній формі повинен вдало і доречно вписуватися в загальну рекламну візуальну комунікаційну концепцію айдентики змагань. Одне із важливих стратегічних завдань розробників елементів олімпійської фрорми - це доступно для споживача висловити сорормульовану фрілософрію збірної країни та Олімпіади в цілому. Дизайн-проєктування одягу виступає в ролі експериментальної території, де тестуються новинки або відбувається апробація історичної ретроспекції. На прикладах дизайн-візуалізації Олімпійської парадної форми визначено концептуальні засади етнодизайну в контексті модифікованої рекламної стратегії, яка відповідає сучасним потребам цільової аудиторії.

\section{Список літератури:}

1. Антонович Є.А. Етноренесанси в культурі XX ст. та їхні етнодизайнерські виміри. Етнодизайн: європейський вектор розвитку і національний контекст : збірн. наук. праць / упорядн. і відп. ред. Є. Антонович. Полтава : ПНПУ, 2015. Кн. 1. С. 7-11.

2. Анхольт С. Бренд Америка: мать всех брендов / Саймон Анхольт, Джереми Хильдрет. Москва : ООО «Издательство «Добрая книга», 2010. URL: http://www.dkniga.ru/upload/iblock/866/866ceeaeb375fb43a46ee1e36c029 c5f.pdf (дата звернення: 03.12.2020).

3. Важенина И., Важенин С. Имидж и репутация как стратегические составляющие нематериальных активов территории. Эконолика региона. 2010. № 3. URL: http://cyberleninka.ru/article/n/imidzh-i-reputatsiya-kakstrategicheskie-sostavlyayuschie-nematerialnyh-aktivov-territorii (дата звернення: 03.12.2020).

4. Гавра Д., Таранова Ю. Имидж территориальных субъектов в современном информационном пространстве. Санкт-Петербург, 2013. 157 с.

5. Гончаренко В.І. Олімпійський спорт : навчальний посібник / Володимир Гончаренко, Ігор Іваній, Анатолій Кудренко : Міністерство освіти і культури України, Сумський державний педагогічний університет ім. А.С. Макаренка. Суми : Видавництво СумДПУ ім. А.С. Макаренка, 2014. 364 с.

6. Легенький Ю.Г. Дизайн: культурологія та естетика. Київський держ. ун-т технологій та дизайну. Київ : КДУТД, 2000. 272 с.

7. Чумиков А.Н. Ч-90 Имидж - репутация - бренд: традиционные подходы и новые технологии : сборник статей. Москва-Берлин : Директ-Медиа, 2015. С. 13.

8. Шандренко O.M. Етномистецтво як джерело модифікації проєктних стратегій формотворення в дизайні одягу. Вісник Харківської державної акаделії дизайну і мистецтв. Мистеитвознавство. Харків, 2014. С. 34-37.

9. Шенерт В. Грядущая реклама. Москва : Интерэксперт, 2001. 302 с.

10. Guidelines (2015) IOC. Guidelines regarding authorised identifications. Games of the XXXI Olympiad, Rio 2016 [2015, April. 1st version].

11. Kane, M. (1960). Splendor and spleen. Sports Illustrated [online], issue 13. Available at: http://www.si.com/ vault/1960/09/05/588793/splendor-and-spleen (accessed 15 December 2020).

12. Long, C. (2012). Winning looks [online] issue July 20. Available at: http://www.ft.com/content/13e35a2a-ccde11e1-b78b-00144feabdc0 (accessed 10 December 2020).

13. Menendez. USOC Announce "Made in America" is Now Permanent USOC Policy [online]. Available at: http://www.menendez.senate.gov/news-and-events/press/menendez-usoc-announce-made-in-america-is-nowpermanent-usoc-policy (accessed 15 December 2020).

14. Moretti, A. (2007). New York Times Coverage of the Soviet Union's Entrance into the Olympic Games. Sport History Review, issue 38.

15. Rogers, T. (1983). Olympic Attire. New York Times [online], issue October 6. Available at: http://www.nytimes.com/ 1983/10/06/sports/scouting-olympic-attire.html (accessed 10 December 2020). 